\title{
20. GEOCHEMISTRY, LEG 35: INTRODUCTION AND SUMMARY
}

\author{
Joris M. Gieskes, Scripps Institution of Oceanography, La Jolla, California \\ and \\ James R. Lawrence, Lamont-Doherty Geological Observatory, Palisades, New York
}

\section{INTRODUCTION}

During Leg 35, an intensive geochemical program was carried out, with the major aim to investigate diagenetic processes that have occurred or continue to occur in the sediments and the underlying basalts in the Bellingshausen area of the Southeast Pacific Ocean. We wish here to emphasize some of the major findings of the various contributors to this effort (Anderson, Donnelly, Drever, Eslinger, Gieskes, Kastner, Lawrence, and Perry), together with substantiating evidence from Soviet contributors to this volume. Details are discussed in the various contributions, so that here we only summarize the major points.

In studying postdepositional diagenetic processes, it is important to study not only the chemical composition of the interstitial waters, but also the chemistry and mineralogy of the solid phases. In addition, one needs to consider the physical properties of the sediments, especially with regard to the transport properties in the interstitial waters. The latter information is particularly useful for the identification of locations in the sediments, where diagenetic reactions appear to occur.

In the following discussion we summarize first the studies on chemistry and mineralogy of the solid phases, then the results on the chemistry of the interstitial waters, and finally the observations on authigenesis in the sediments and basalts, together with oxygen isotope mass balance considerations.

\section{SEDIMENT MINERALOGY AND CHEMISTRY}

Mineralogical data are presented in the contributions of Zemmels and Cook, Drever, Gorbunova, Perry et al., Kastner, and Bogdanov et al. Chemical data can be found in the papers of Bogdanov et al., Donnelly and Wallace, Drever, and Perry et al.

In general, the sediments of late Miocene age and younger are dominated by terrigenous material, whereas sediments of Miocene and Oligocene age and older have appreciable volcanic components (glass shards). Donnelly and Wallace find the entire sediment column to be isochemical in the bulk chemical composition. They argue that authigenic minerals (montmorillonite, clinoptilolite, K-feldspar) in the deeper parts of Site 322 ( $>438$ $\mathrm{m})$ and Site $323(>638 \mathrm{~m})$ are primarily due to isochemical alteration of an undefined nature of a terrigenous suite of minerals. On the other hand, Drever, Perry et al., and Kastner propose that these authigenic minerals are typical alteration products of volcanic ash or glass. Perhaps we are dealing with andesitic material, with chemical characteristics similar to those of continentally derived material so that, on the basis of chemical information alone, no definite conclusions can be reached. This problem deserves further attention.

\section{Site 322}

The sediments above 438 meters are generally of terrigenous origin, with the clay fraction dominated by a detrital illite/smectite, illite, and chlorite assemblage. Below this depth, there occurs a mineralogical break, evidenced by a proportionally larger amount of illite/ smectite with greater than $80 \%$ smectite layers (Perry et al., Kastner). This material is most likely of volcanic origin. Toward the base of the section, just above the basalt, there is a progressive increase in terrigenous material, evident from an increase in illite and a decrease in illite/smectite.

The observation of an increased amount of terrigenous debris toward basalt basement is of importance. No evidence has been found for baking of the sediments, but the basal 4 meters of sediments are slightly enriched in $\mathrm{Fe}, \mathrm{Mn}$, and $\mathrm{PO}_{4}$ (Donnelly). Gorbunova and Bogdanov et al. suggest that this may be due to redeposition of ridge crest material of hydrothermal origin. Underlying basalts show only minor evidence of alteration and were probably covered rapidly by sediments of both terrigenous and volcanic origin. It is not certain whether the increased contents in $\mathrm{Fe}$ and $\mathrm{Mn}$ are due to presence of ridge crest material or to enrichments in situ as a result of the alteration of volcanic material. Finally, it is possible that an actual hiatus occurs at the sediment-basalt interface. Typically, the age of the basal section is similar to the age of the sediment overlying the unconformity at Site 323 .

\section{Site 323}

The sediments above 638 meters are dominated by terrigenous material. Diatoms disappear below 400 meters, apparently due to recrystallization to porcellanite and siliceous claystones. In addition to the formation of porcellanite around 450 and 500 meters, the alteration of volcanic material is significant (Anderson and Lawrence; Kastner).

The clay mineral suite below 638 meters is dominated by illite/smectite, with $>80 \%$ smectite. This material is associated with clinoptilolite and possibly authigenic feldspar (Zemmels and Cook; Drever). We have already mentioned the variance in opinion on the genesis of this secondary mineral assemblage. Of interest is the decrease in the $\mathrm{K} / \mathrm{Al}$ ratio in the clay fraction and the constancy of this ratio in the bulk sediment. This evidence can again be used with equal strength in the case for or against diagenetic alteration of terrigenous material. 
Of considerable interest are the high $\mathrm{Fe} / \mathrm{Mn}$-bearing sediments between 638 and 669 meters, which sandwich two or three rather thin layers of nannofossil chalk. These sediments are also enriched in trace metals (Bogdanov et al.; Drever) as well as in strontium and phosphorus. Barium increases toward basement, below this metal-enriched zone. Bogdanov et al. suggest a hydrothermal origin of this material, as a result of the upward motion of waters of hydrothermal origin through the basalts and overlying sediments. These fluids would first lose their $\mathrm{Ba}$, due to barite precipitation. Subsequently, oxidation and precipitation of $\mathrm{Fe}$ and $\mathrm{Mn}$, as well as the other metals, would occur in the oxidizing upper sediment layers. Although speculative in nature, this interpretation is in agreement with the observation of possible "hydrothermal" alteration in the underlying basalts (Kastner).

\section{Site 324}

The mineralogy of this site is dominated by a terrigenous suite of minerals. Minor amounts of clinoptilolite (Gorbunova; Zemmels and Cook) were noticed in the sediments above 110 meters, possibly as a result of alteration of minor amounts of volcanic glass, which were also seen in these sediments.

\section{Site 325}

The upper part of this section is again dominated by a detrital suite of minerals, and only below 630 meters does an illite/smectite of authigenic origin become a dominant clay fraction component. Slightly increased $\mathrm{Mg} / \mathrm{Al}$ ratios of these sediments (Donnelly and Wallace) may reflect this. Of interest here is the essentially zero concentration of magnesium in the interstitial waters in this sediment section.

In general, the mineralogies of the sediments of Sites 322 and 325 are very similar, with volcanic components becoming of importance in the lowermost sections.

Oxygen isotope studies on sediments of Sites 322,323 , and 325 suggest a predominant terrigenous detrital suite of silicates (Anderson and Lawrence). Slight enrichments in $\delta \mathrm{O}^{18}$ in the basal brown claystones $(>638 \mathrm{~m})$ at Site 323 suggest the possibility of low temperature alteration of volcanic debris. This interpretation is strengthened by the similarity in $\delta \mathrm{O}^{18}$ in the bulk silicate (Anderson and Lawrence) and the $<1 \mu \mathrm{m}$ clay and quartz fraction (Eslinger and Savin).

Gorbunova interprets the high degree of crystallinity of the montmorillonites below 638 meters at Site 323 in terms of interaction of fluids of hydrothermal origin with these sediments, without a specific knowledge of precursors.

\section{CHEMISTRY OF THE INTERSTITIAL WATERS}

Due to the rather unusual occurrence of high strontium contents in the high $\mathrm{Fe} / \mathrm{Mn}$ sediments of Site 323, which subsequently caused a well-defined dissolved strontium concentration gradient in the pore fluids, we were successful in testing the usefulness of formation factor data to study the diffusional properties of these sediments. Using this information, we were able to postulate "reaction zones" in the sediment column in which release of dissolved calcium and uptake of dis- solved magnesium and potassium occur. From the concentration-depth profiles, we deduce the following important reaction zones.

\section{Site 322}

In the upper Pliocene/Pleistocene sediment, there occurs a release of $\mathrm{Ca}^{++}$and simultaneous decrease in $\mathrm{Mg}^{++}$, possibly related to alteration of terrigenous debris (Peters and Hollister). Further release of $\mathrm{Ca}^{++}$ and uptake of $\mathrm{Mg}^{++}$appear to be of importance in the lowermost sediments or in the underlying basalts. The data for dissolved potassium suggest a minor sink in the basal sediments or in the underlying basalts. Changes in the oxygen isotope composition are small, suggesting little ongoing alteration either in the sediments or in the underlying basalts (Lawrence et al.).

Depletions in dissolved sulfate are small, which is also reflected in the small increases in alkalinity and ammonia in the upper part of the hole. The continuous decrease in alkalinity (and total $\mathrm{CO}_{2}$ ) below 300 meters indicates the removal of carbon dioxide during the alteration processes involving the $\mathrm{Ca}^{++}$increases and $\mathrm{Mg}^{++}$decreases observed. Fairly high manganese concentrations indicate prevailing reducing conditions throughout the hole.

\section{Site 323}

Again, a source of dissolved calcium and a sink for magnesium is situated in the Pliocene/Pleistocene sediments (alteration of terrigenous debris?). Furthermore, the data indicate a further source of $\mathrm{Ca}^{++}$and sink for $\mathrm{Mg}^{++}$in the sediment layers at about 450 meters (alteration of volcanic material, Kastner). Finally, a further source for $\mathrm{Ca}^{++}$and sink for $\mathrm{Mg}^{++}$is located in the basal sediments or in the underlying basalts. Potassium sinks are located at 450 meters and in the basal sediments or basalts. Changes in $\delta \mathrm{O}^{18}$ of the interstitial waters show large depletions, especially in the lower sediment section. Alteration of volcanic matter and/or basalt must still be of importance in these sediments (Lawrence et al.).

\section{Site 324}

The Pliocene/Pleistocene sediments indicate that a source for dissolved calcium was present in the sediments, leading to a maximum concentration at about 115 meters which may again be due to the same processes active in Sites 322 and 323 in similar horizons. Small amounts of clinoptilolite (Zemmels and Cook) and glass shards, however, could mean alteration of volcanic matter. Changes in $\delta \mathrm{O}^{18}$ are relatively large. Unfortunately, we do not know much about the nature of the underlying sediments, so that interpretations of interstitial water composition are necessarily hampered.

\section{Site 325}

Again, a source for calcium and sink for magnesium are located in the upper sediments. High sedimentation rates in the upper section allow the lower sediments to become essentially a closed system. As a result, complete depletion of magnesium occurs in the lower sections that are characterized by larger volcanic contributions (Perry et al.; Gorbunova). Dissolved calcium shows very large 
increases, probably due to alteration of underlying basalts(?).

In general, the data suggest that postdepositional alteration reactions are important in these sediments. Changes in $\delta \mathrm{O}^{18}$ of the interstitial fluids indicate that alteration of volcanic debris or basalt is of importance. The alteration reactions involve the uptake of magnesium (montmorillonite) and of potassium (zeolites, Kfeldspar?) from the interstitial waters and the release of $\mathrm{Ca}$ (from plagioclase and augite). Alkalinity decreases toward the deeper parts of the hole, as does the total $\mathrm{CO}_{2}$ content. This can best be understood in terms of the precipitation of calcium carbonate. Indeed, authigenic calcite shows very low $C^{13} / C^{12}$ ratios $\left(\delta C^{13}\right.$ as low as $-20 \%$, Anderson and Lawrence) indicating a primarily biogenic source of carbon dioxide (due to sulfate reduction) and involving a small amount of the calcium released during the alteration reactions described above. The alteration reactions also will involve changes in alkalinity, but little can be said about quantitative amounts involved, since we lack precise information on the reaction mechanisms.

\section{AUTHIGENESIS IN SEDIMENTS AND BASALTS}

In the previous sections we have indicated that there is abundant information to indicate that extensive authigenic reactions have occurred in these sediments. The lower sections of Sites 322 and 323 especially show a secondary mineral assemblage with typical authigenic components: illite/smectite with $>80 \%$ smectite; clinoptilolite; K-feldspar (?). In addition, the interstitial water gradients, particularly at Site 323 , suggest zones where diagenetic reactions appear to be ongoing. A detailed study of a slab of claystone and porcellanite at 450 meters in Hole 323 (Anderson and Lawrence; Kastner) indicates that $\delta \mathrm{O}^{18}$ changes are related both to recrystallization of biogenous silica and to alteration reactions of volcanic material. Kastner shows the presence of authigenic montmorillonite and $\mathrm{K}$-feldspar in these claystones. The alteration reactions leading to these products appear to be sinks for magnesium and potassium and sources for calcium in the interstitial fluids. It appears that, for the first time, the actual reactions causing large changes in the interstitial water composition have clearly been identified.

Of major interest is the alteration of the underlying basalts in Holes 322 and 323 . Evidence on the major ion composition $\left(\mathrm{Ca}^{++}, \mathrm{Mg}^{++}, \mathrm{K}^{+}\right)$and on changes in $\delta \mathrm{O}^{18}$ of the interstitial water suggests release of $\mathrm{Ca}^{++}$and uptake of $\mathrm{K}^{+}$and $\mathrm{Mg}^{++}$at both sites, but with the extent of reaction at Site 323 being far larger than at Site 322 .

Alteration products at Site 322 are typically poorly crystallized smectite, phillipsite, and some minor amounts of calcite. In contrast, alteration products at Site 323 are well-crystallized smectite, celadonite, goethite, and abundant calcite in veins. Kastner interprets these differences in terms of alteration of basalts at Site 323 due to interaction $\left(<50^{\circ} \mathrm{C}\right)$ with fluids of possible hydrothermal origin. This interpretation would be consistent with the suggestion of a hydrothermal origin of barium enrichments and high $\mathrm{Fe} / \mathrm{Mn}$ sediments at some distance above basement (Bogdanov et al.). The hydrothermal activity must have occurred after burial below a relatively thin sediment column. At Site 322 , no evidence is present for hydrothermal activity, thus leading to different alteration products and less alteration.

Data on oxygen isotope compositions of basalts and alteration products at Site 323 suggest generally low temperature reactions. The lower basalts show the $\mathrm{C}^{13}$ contents of carbonate veins to be in equilibrium with seawater at low temperatures. The carbonate veins in the uppermost basalt layers become increasingly lighter in $\mathrm{C}^{13}$, clear evidence for continued alteration after burial below a sediment cover. The $\mathrm{CO}_{2}$ involved in the alteration process is then due to the bacterial decomposition of organic matter in these overlying sediments.

\section{CONCLUSIONS}

Geochemical and mineralogical studies of interstitial waters, sediments, and basalts recovered during Leg 35 have revealed the following aspects of the geochemistry of sediments and basalts in the Bellingshausen area:

1) Sediments of Pliocene age and younger are mainly of terrigenous origin. Mineralogies of the clays and high $\mathrm{K} / \mathrm{Al}$ ratios in the sediments suggest most of this material is derived from the Antarctic continent. Minor amounts of volcanic debris and/or ice-rafted material (especially in the Pliocene/Pleistocene) may account for the small amounts of clinoptilolite, as well as for the increases in dissolved calcium and decreases in magnesium in the interstitial fluids. Sediments of Oligocene age and older show a secondary mineral assemblage that probably is due to alteration of andesitic volcanic debris, although it has also been suggested that it could be due to alteration of a terrigenous suite of detrital sediments similar to the sediments in the upper parts of the sites.

2) Gradients in dissolved calcium, magnesium, and potassium in the interstitial waters define zones in which diagenetic reactions occur. At Site 323, some of these reactions have been identified in terms of alteration of plagioclase (source for $\mathrm{Ca}^{++}$), formation of smectite (sink for $\mathrm{Mg}^{++}$), and authigenic $\mathrm{K}$-feldspar (sink for $\mathrm{K}^{+}$). This is the first time that such clear identification of reaction sites has been made. Evidence from calcium gradients, especially, points toward continued alteration of underlying basalts, especially at Sites 323 and 325 .

3) Studies of the oxygen isotopes in interstitial waters and silicates indicate that substantial alteration of volcanic material and/or basalt still occurs in the various sites, particularly at Sites 323 and 325 . Studies of carbon isotopes of authigenic calcite in the sediments and in the calcite veins of basalts of Site 323 indicate that much of the carbon is derived from diagenetic alteration of organic carbon. The light carbon in basalt veins is clear evidence for continued alteration of basalts long after burial below a thick sediment column.

4) Alteration reactions of basalts at Sites 322 and 323 must have occurred under much different conditions.Whereas relatively minor alteration has occurred at Site 322 , leading to poorly crystallized smectite and philipsite, the alteration products of Site 323 basalts are well crystallized smectite and celadonite, as well as calcite and goethite. The hypothesis of "hydrothermal" origin of the alteration at Site $323\left(t<50^{\circ} \mathrm{C}\right)$ is supported by 
chemical and mineralogical data on barium and $\mathrm{Fe} / \mathrm{Mn}$ enrichments in the overlying sediments.

\section{ACKNOWLEDGMENTS}

We wish here to acknowledge the cooperation of our colleagues Drs. Anderson, Donnelly, Drever, Eslinger, Kastner, and Perry in this joint effort. We believe that only through such a concentrated effort can we obtain a reasonably complete understanding of the diagenetic processes affecting deepsea sediments. The Deep Sea Drilling Project generously supported a meeting of all the above scientists. Most of the work was supported by the National Science Foundation (appropriate acknowledgments are in the individual contributions). 